\title{
Potentiality of Potassium Solubilizing Bacteria on Enhancing the Growth, Yield and Nutrient Acquisition on Wheat (Triticum aestivum L.)
}

\author{
Gajendra Meena* and Bihari Ram Maurya \\ Department of Soil Science and Agricultural Chemistry, Institute of Agricultural Sciences, \\ Banaras Hindu University, Varanasi 221005, Uttar Pradesh, India \\ *Corresponding author
}

\section{A B S T R A C T}

Keywords

Potassium solubilizing bacteria (KSB), Potassium $(\mathrm{K}), \mathrm{KSB}$ isolates

Article Info

Accepted:

20 March 2017

Available Online:

10 April 2017
Soil potassium supplementation relies heavily on the use of chemical fertilizer, which has a considerable negative impact on the environment. There is a growing need to turn back to nature or sustainable agents that promote evergreen agriculture. Among such natural bio-agents, the potassium solubilizing bacteria (KSB), which solubilize fixed forms of potassium (K) and increase growth, yield and nutrient uptake of wheat plant and hence Soil fertility can be restored effectively through adopting concept of integrated soil fertility management (ISFM). A pot experiment conducted to study the effect of KSB isolates in wheat plant. Soil and leaf samples were drawn from the respective plots and they were subjected for the analysis of various parameters related to nutrients and quality aspects. Plants treated with different KSB isolate without potassium fertilizer. Among various treatments five isolates were in order of KSB $107>\mathrm{KSB} 37>\mathrm{KSB} 54>\mathrm{KSB} 48>\mathrm{KSB}$ 1008-4 found positive effect on growth and yield of wheat crop as well as gave better nutrient uptake.

\section{Introduction}

Potassium is one of 17 vital nutrients required for the growth and reproduction of plant. Potassium is one of the mass nutrients essential for wheat growth and development. Most of the $\mathrm{K}$ in soil exists in various insoluble rocks, minerals, and sedimentary materials (Goldstein, 1994). Excessive usage of fertilizers leads to the leaching of nutrients from the soil and contributes to environmental pollution, without corresponding increases in yield. In contrast, insufficient fertilizer application in countries where resources are limited results suboptimal yields. Biofertilizer is an alternative path to meet mineral to crop requirement, especially in case of potassium mineral because it fixed with in soil and not easily meet to crop Although most agricultural soils have large amounts of $\mathrm{K}$, these are immobilized and mostly become unavailable. Hence, very limited concentration of $\mathrm{K}$ is available to plants due to $\mathrm{K}$ deficient in soils The amount of potassium present in the soil solution is often smaller than the wheat crop requirement for potassium. With the use of K-solubilizing microbes the concentration of available $\mathrm{K}$ ions can be increase in the soil which may further reduce $\mathrm{K}$ deficiency (Barker et al., 1998). There is many research has done in previous year on KSB and their working mechanism. The use of KSB as a biological fertilizer is a hotspot for the study of 
agriculture and environmental conservation (Deng et al., 2003). The application of organo-minerals with the combination of silicate bacteria for enhancing plant growth and yield of maize and wheat was first reported by Aleksandrov (1967). Therefore, the use of KSB in agricultural practice would not only offset the high cost of manufacturing potassic fertilizers but would also mobilize insoluble fertilizers in the soils to which they are applied. Use of phosphate bio-fertilizers decreases the detrimental effects of phosphate fertilizers on crop and soil health. Xie (1998), Archana et al., (2008) reported that the KSMs was isolated from rock and rhizosphere soils of green gram (Vigna radiata) reported that these KSMs enhanced the solubilisation of $\mathrm{K}$ in acid leached soil as well as increased seedling growth and yield of green gram.

\section{Potassium solubilizing microorganisms and their occurrence}

Different bacterial species like silicate bacteria were found to dissolve potassium, silicates and aluminium from insoluble minerals (Aleksandrov, 1967) Muentz reported the first evidence of microbial involvement in solubilization of rock potassium (Muentz, 1890). Microorganisms like Bacillus mucilaginosus, Aspergillus niger, Bacillus extroquens and Clostridium pasteurianum were found to grow on muscovite, biotite, orthoclase microclase and mica in vitro (Archana, 2013).

\section{Materials and Methods}

\section{KSB strain for pot application}

The indigenous potassium solubilizing bacteria strain obtained from soil microbiology laboratory of Institute of Agriculture science BHU, India was selected based on prior knowledge of their higher potassium solubilization rate and production of phytohormones (Bagyalakshmi et al., 2009). The selected KSB strain was formulated using jagary as priming application and seed shown directly up to 5 $\mathrm{cm}$ depth in pot.

\section{Bacterial strains}

$K S B$ isolated from potassium mining. The BHU farm soil used in this study and put in clay pot without any potassic synthetic fertilizers had been used during experiment Nitrogenous and phosphoric fertilizer used to maintain the soil fertility. Bacterial strains were cultivated on Aleksandrov medium $(\mathrm{Hu}$ et al., 2006). The composition of Aleksandrov medium $5.0 \mathrm{~g}$ glucose, 0.005 magnesium sulphate $\left(\mathrm{MgSO}_{4} .7 \mathrm{H}_{2} \mathrm{O}\right), 0.1 \mathrm{~g}$ ferric chloride $\left(\mathrm{FeCl}_{3}\right), 2.0 \mathrm{~g}$ calcium carbonate, $3.0 \mathrm{~g}$ potassium mineral Mica (biotite), $2.0 \mathrm{~g}$ calcium phosphate, $20 \mathrm{~g}$ Agar-agar in 1000 $\mathrm{mL}$ of Distilled water Pot experiment. A oneyear pot experiment was conducted in the Net house of institute of agriculture science of Banaras Hindu University. This site was situated at between $25^{\circ} 18^{\prime}$ North latitude and $80^{0} 36^{\prime}$ East longitude.

\section{Efficiency of Potassium Solubilizing} Bacteria (KSB) on Nutrient uptake, growth and yield parameters of Wheat plants under Net house

A pot culture experiment was conducted using fifteen efficient potassium solubilizing bacterial isolates which were used with recommended dose N:P:K (120:60:40) fertilizers in combination to study their effect on growth, yield, $\mathrm{K}$ content of Wheat as detailed below. Experiment design was CRD (Complete Randomized Design) with 15 Number of isolates with three replication in 45 pots and 3 control. Fertilizer applies in ratio of 120:60 for $\mathrm{N}$ and $\mathrm{P}_{2} \mathrm{O}_{5}$ respectively. Malviya 234 (HUW-234) crop variety takes in rabi season of 2015- 16. The isolates used 
for pot culture experiment are presented in table 1 .

\section{Yield assessment}

Number of leaves per plant counted and recorded by manually at 30, 45 and 60 day after sowing Plant height of wheat crop measured by meter scale from base of plant at 30, 45, 60, 75, and 90 Day after sowing. Plant chlorophyll determine by chlorophyll meter SPAD-502 MINOLTA at 30, 45 and 60 Day after sowing.

In Yield parameters Tillers which produced spike were counted manually. Spike length was measured with the help of meter scale manually after harvesting the crop. Number of spike was counted and recorded manually. Total 100 grains were randomly selected from each pot and their weight was recorded and expressed in grams. Test weight was measured with the help of electrical balance and recorded and expressed in g/plant. At maturity, plant in each pot was harvested and weighted with the help of balance and recorded total biological yield. Grains were separated by beating the ears by wooden rods and weight using electrical balance and expressed in $g$ plant $^{-1}$. Straw weight was recorded with the help of electrical balance and expressed in $\mathrm{g}$ plant $^{-1}$ Harvest index was calculated with the help of formula as below;

$\begin{aligned} & \text { Harvest } \\ & \text { Index }\end{aligned}=\frac{\text { Economic Yield }}{\text { Total Yield }} \quad 100$

\section{Statistical analysis and interpretation of data}

The raw data generated during the whole experiment were subjected to statistical analysis by following the Complete Randomized Design (CRD) with the appropriate ANOVA table. Overall significance of treatments was tested by F-test and further comparisons were made with the critical difference (CD) at 5\% degree of significance to draw the valid differences among the treatments.

\section{Results and Discussion}

\section{Effect of potassium solubilizing bacteria on the growth and yield wheat crop}

In the background of unstable fertilization, lower potash application results in a major depletion of soil potash reserves, yield loss and higher economic risk for farmers. KSB isolates that are able to dissolve potassium from mineral and rocks have influence on plant growth and have both economic and environmental advantage. Tables 2 and 3 summarize effect of potassium solublizing bacteria on growth and yield on wheat crop under Net House condition respectively.

Maximum and significantly higher SPAD value was recorded with KSB 36 (39.76) followed by KSB 31 (39.59) compared to control. KSB 107 caused significantly higher $64.39 \mathrm{~cm}$ plant height than control. Plant height increased from 60 DAI to 75 DAI. KSB 37 caused significantly higher leaves plant $^{-1}$ than control and it was at par with 3 KSB isolates. Plant height increased with about 11 per cent increase compare to control. Out of $15 \mathrm{KSB}$ isolates $11 \mathrm{KSB}$ isolates showed significant superiority in number of tillers over control. KSB107 showed significantly higher number of effective tillers (2.60) than control.

Maximum spike length was recorded with KSB 48 followed by KSB 22 which is increased by 8 per cent. Number of grains per pot was significantly more than all isolates. KSB 107 produces maximum 189.33 grains pot $^{-1}$ which increased with about 73 per cent compare with control. KSB 36 showed maximum value of grains spike ${ }^{-1}$ which is 
increased by 40 per cent compares to control. KSB 107 gave highest and significant by more grain yield pot $^{-1}$ over all isolates which was 33\% more than control. Maximum straw yields and total biomass were recorded with isolates KSB 107. Content of $\mathrm{K}$ in grain, straw and in soil at harvest were influenced by KSB isolates.

Table.1 Isolates detail

\begin{tabular}{|c|c|c|c|}
\hline S.No. & Isolates & S.No. & Isolates \\
\hline 1 & KSB 40 & 9 & KSB 19 \\
2 & KSB 28 & 10 & KSB 31 \\
3 & KSB 111 & 11 & KSB 1008-4 \\
4 & KSB 9 & 12 & KSB 48 \\
5 & KSB 15 & 13 & KSB100 \\
6 & KSB 54 & 14 & KSB 107 \\
7 & KSB 37 & 15 & KSB 22 \\
8 & KSB 36 & & \\
\hline
\end{tabular}

Table. 2 effect of KSB isolates on growth attributes of wheat crops

$\begin{array}{lllll}\text { KSB isolates } & \begin{array}{l}\text { Chlorophyll } \\ \text { SPAD value }\end{array} & \begin{array}{l}\text { plant height in } \\ \text { cm }\end{array} & \begin{array}{l}\text { Number of } \\ \text { leaves per plant }\end{array} & \text { Tillers per plant } \\ \text { Control } & 38.4 & 57.02 & 9.01 & 1.48 \\ \text { KSB 40 } & 39.21 & 59.35 & 9.66 & 2.13 \\ \text { KSB 28 } & 36.47 & 58.12 & 9.85 & 1.66 \\ \text { KSB 111 } & 39.68 & 63.24 & 9.94 & 1.8 \\ \text { KSB 9 } & 38.71 & 61.28 & 9.87 & 2.03 \\ \text { KSB 15 } & 38.48 & 62.15 & 9.26 & 2.26 \\ \text { KSB 54 } & 38.62 & 59.38 & 9.41 & 2.33 \\ \text { KSB 37 } & 38.61 & 63.56 & 10.89 & 2.16 \\ \text { KSB 36 } & 39.76 & 61.51 & 10.01 & 2.38 \\ \text { KSB 19 } & 39.18 & 61.66 & 10.27 & 2.23 \\ \text { KSB 31 } & 39.59 & 60.88 & 9.86 & 2.17 \\ \text { KSB 1008-4 } & 37.31 & 62.95 & 9.87 & 2.21 \\ \text { KSB 48 } & 37.69 & 62.18 & 10.68 & 2.46 \\ \text { KSB100 } & 37.02 & 62.44 & 10.22 & 2.08 \\ \text { KSB 107 } & 37.51 & 64.39 & 9.6 & 2.19 \\ \text { KSB 22 } & 38.08 & 60.6 & 10.06 & 2.36\end{array}$


Table.3 Effect of KSB isolates on yield attributes of wheat crop

\begin{tabular}{|c|c|c|c|c|c|c|c|c|}
\hline $\begin{array}{l}\text { KSB } \\
\text { isolates }\end{array}$ & $\begin{array}{l}\text { Effective } \\
\text { tillers } \\
\text { plant }^{-1}\end{array}$ & $\begin{array}{l}\text { Spike } \\
\text { length } \\
\text { (cm) }\end{array}$ & $\begin{array}{l}\text { Grains } \\
\text { pot }^{-1}\end{array}$ & $\begin{array}{l}\text { Grains } \\
\text { spike }\end{array}$ & $\begin{array}{l}\text { Grain } \\
\text { yield } \\
\text { pot }^{-1} \\
\text { (g) }\end{array}$ & $\begin{array}{l}\text { Straw } \\
\text { yield } \\
\text { pot }^{-1} \\
(\mathrm{~g})\end{array}$ & $\begin{array}{l}\text { Total } \\
\text { biomas } \\
\text { pot }^{-1} \\
\text { (g) }\end{array}$ & $\begin{array}{l}\text { harvest index in } \\
\text { per cent }\end{array}$ \\
\hline Control & 1.59 & 11.66 & 50 & 16.68 & 2.63 & 3.11 & 5.75 & 46 \\
\hline KSB 40 & 2.23 & 12.02 & 82 & 20.5 & 3.97 & 5.01 & 8.98 & 44 \\
\hline KSB 28 & 1.78 & 11.86 & 99.33 & 24.2 & 5.07 & 6.31 & 11.37 & 45 \\
\hline KSB 111 & 2.1 & 12.33 & 42.67 & 20.77 & 4.83 & 7.88 & 12.71 & 38 \\
\hline KSB 9 & 2.1 & 12.28 & 69.33 & 20.41 & 2.63 & 3.5 & 6.13 & 43 \\
\hline KSB 15 & 2.42 & 11.47 & 82.33 & 20.62 & 3.9 & 5.01 & 8.91 & 44 \\
\hline KSB 54 & 2.54 & 11.84 & 110.33 & 22.29 & 5.67 & 6.98 & 12.64 & 45 \\
\hline KSB 37 & 2.15 & 12.31 & 163 & 25.12 & 7.01 & 8.7 & 15.71 & 45 \\
\hline KSB 36 & 2.57 & 10.7 & 89.33 & 27.82 & 4.73 & 6.47 & 11.21 & 42 \\
\hline KSB 19 & 2.35 & 12.34 & 84.67 & 25.18 & 5.41 & 7.03 & 12.44 & 43 \\
\hline KSB 31 & 2.23 & 11.07 & 67.33 & 23.43 & 4.03 & 5.05 & 9.08 & 44 \\
\hline KSB 1008-4 & 2.38 & 11.96 & 148 & 22.5 & 4.83 & 8.65 & 13.48 & 36 \\
\hline KSB 48 & 2.55 & 12.7 & 121.33 & 23.79 & 6.4 & 8 & 14.4 & 44 \\
\hline KSB100 & 2.38 & 12.31 & 126 & 25.59 & 5.07 & 6.47 & 11.54 & 44 \\
\hline KSB 107 & 2.6 & 12.09 & 189.33 & 27.08 & 7.87 & 10.42 & 18.29 & 43 \\
\hline KSB 22 & 2.29 & 12.64 & 105.33 & 26.14 & 5.17 & 6.37 & 11.54 & 45 \\
\hline
\end{tabular}

\begin{tabular}{|lcccccc|}
\hline & \multicolumn{3}{c}{ Table.4 Effect of KSB isolates on per cent content of P in straw and grain wheat crop } \\
\hline & \multicolumn{2}{c}{ Content of K (\%) } & Content of N (\%) & \multicolumn{3}{c|}{ Content of P (\%) } \\
\cline { 2 - 7 } KSB isolates & Straw & Grain & Straw & Grain & Straw & Grain \\
\hline Control & 1.08 & 0.27 & 0.31 & 1.44 & 0.03 & 0.24 \\
KSB 40 & 1.43 & 0.42 & 0.39 & 1.63 & 0.04 & 0.33 \\
KSB 28 & 1.62 & 0.49 & 0.33 & 1.67 & 0.05 & 0.41 \\
KSB 111 & 1.41 & 0.38 & 0.44 & 1.72 & 0.04 & 0.37 \\
KSB 9 & 1.52 & 0.42 & 0.41 & 1.53 & 0.04 & 0.35 \\
KSB 15 & 1.61 & 0.46 & 0.41 & 1.62 & 0.04 & 0.3 \\
KSB 54 & 1.35 & 0.38 & 0.39 & 1.74 & 0.05 & 0.38 \\
KSB 37 & 1.55 & 0.35 & 0.42 & 1.51 & 0.05 & 0.37 \\
KSB 36 & 1.6 & 0.5 & 0.41 & 1.97 & 0.07 & 0.35 \\
KSB 19 & 1.49 & 0.46 & 0.43 & 1.96 & 0.05 & 0.34 \\
KSB 31 & 1.58 & 0.47 & 0.39 & 1.83 & 0.06 & 0.37 \\
KSB 1008-4 & 1.53 & 0.45 & 0.41 & 1.75 & 0.04 & 0.27 \\
KSB 48 & 1.52 & 0.44 & 0.39 & 1.83 & 0.07 & 0.47 \\
KSB100 & 1.42 & 0.41 & 0.39 & 1.78 & 0.06 & 0.3 \\
KSB 107 & 1.64 & 0.51 & 0.44 & 1.99 & 0.08 & 0.44 \\
KSB 22 & 1.4 & 0.39 & 0.38 & 1.81 & 0.05 & 0.32 \\
\hline
\end{tabular}


Table.5 Effect of KSB isolates on uptake of nutrient $\left(\mathrm{mg} \mathrm{pot}^{-1}\right)$ of wheat crop

\begin{tabular}{|c|c|c|c|c|c|c|c|c|c|}
\hline \multirow[t]{2}{*}{ KSB isolates } & \multicolumn{3}{|c|}{ Uptake of $N\left(\mathrm{mg} \mathrm{pot}^{-1}\right)$} & \multicolumn{3}{|c|}{ Uptake of $P\left(\mathrm{mg} \mathrm{pot}^{-1}\right)$} & \multicolumn{3}{|c|}{ Uptake of $K\left(\mathrm{mg} \mathrm{pot}^{-1}\right)$} \\
\hline & $\begin{array}{l}\text { by } \\
\text { straw }\end{array}$ & $\begin{array}{l}\text { by } \\
\text { grain }\end{array}$ & $\begin{array}{l}\text { Total } \\
\text { uptake }\end{array}$ & $\begin{array}{l}\text { by } \\
\text { straw }\end{array}$ & $\begin{array}{l}\text { by } \\
\text { grain }\end{array}$ & $\begin{array}{l}\text { Total } \\
\text { uptake }\end{array}$ & $\begin{array}{l}\text { by } \\
\text { straw }\end{array}$ & $\begin{array}{l}\text { by } \\
\text { grain }\end{array}$ & $\begin{array}{l}\text { Total } \\
\text { uptake }\end{array}$ \\
\hline Control & 9.7 & 38.2 & 47.9 & 1.04 & 6.39 & 7.43 & 33.48 & 7.17 & 40.65 \\
\hline KSB 40 & 19.7 & 64.4 & 84.1 & 1.84 & 13 & 14.84 & 71.43 & 16.82 & 88.25 \\
\hline KSB 28 & 21 & 84.4 & 105.4 & 4.19 & 21.02 & 25.21 & 102.32 & 24.73 & 127.05 \\
\hline KSB 111 & 34.5 & 83.2 & 117.7 & 3.67 & 18.16 & 21.83 & 110.61 & 18.16 & 128.77 \\
\hline KSB 9 & 14.4 & 40.4 & 54.8 & 1.52 & 9.1 & 10.62 & 53.16 & 10.98 & 64.14 \\
\hline KSB 15 & 20.8 & 63 & 83.8 & 2.5 & 17.04 & 19.54 & 80.6 & 18.05 & 98.65 \\
\hline KSB 54 & 27.5 & 98.7 & 126.2 & 3.23 & 21.17 & 24.4 & 94.4 & 21.34 & 115.74 \\
\hline KSB 37 & 36.9 & 105.7 & 142.6 & 4.08 & 26.59 & 30.67 & 134.45 & 24.77 & 159.22 \\
\hline KSB 36 & 26.7 & 94.7 & 121.4 & 4.53 & 15.57 & 20.1 & 103.87 & 23.7 & 127.57 \\
\hline KSB 19 & 29.5 & 108.5 & 138 & 3.52 & 18.4 & 21.92 & 116.09 & 27.52 & 143.61 \\
\hline KSB 31 & 22.2 & 76.4 & 98.6 & 3.17 & 14.82 & 17.99 & 79.69 & 19.09 & 98.78 \\
\hline KSB 1008-4 & 35.7 & 85.4 & 121.1 & 3.46 & 13.2 & 16.66 & 131.67 & 21.88 & 153.55 \\
\hline KSB 48 & 31.7 & 116.5 & 148.2 & 6.19 & 29.96 & 36.15 & 122.11 & 28.2 & 150.31 \\
\hline KSB100 & 25.4 & 90.2 & 115.6 & 3.88 & 15.19 & 19.07 & 91.59 & 20.55 & 112.14 \\
\hline KSB 107 & 40.6 & 154.8 & 195.4 & 5.21 & 23.62 & 28.83 & 155.43 & 36.37 & 191.8 \\
\hline KSB 22 & 24.1 & 94.3 & 118.4 & 3.19 & 16.45 & 19.64 & 89.74 & 19.88 & 109.62 \\
\hline
\end{tabular}

Figure.1 Effect of KSB isolates on grain, straw and total bio mass of wheat crop at harvest

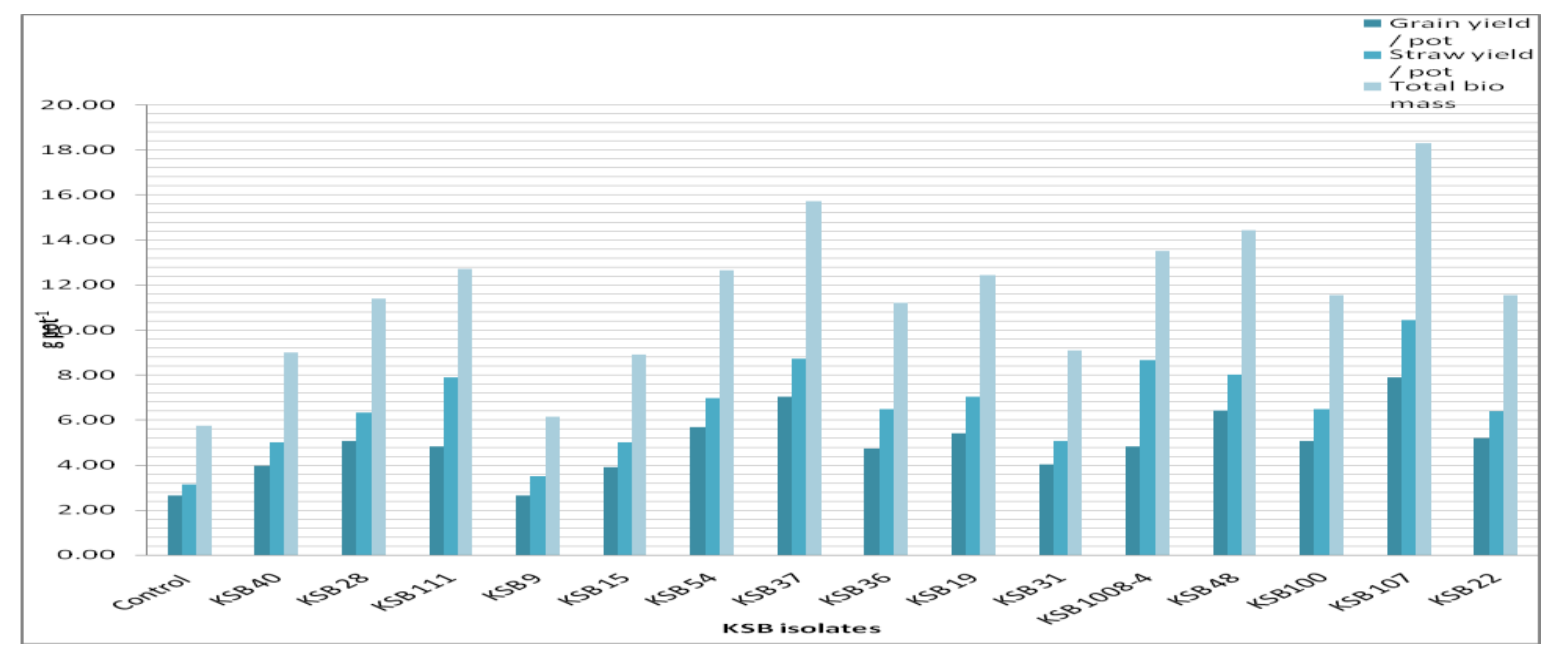

Effect of potassium solubilizing bacteria on content and uptake of primary nutrient in wheat

There was $65 \%$ increase in potassium content in straw due to inoculation of KSB 107 than un-inoculated. Maximum K content in straw was recorded with isolates KSB 107 (1.64\%) which was significantly superior to $10 \mathrm{KSB}$ isolates. Increase in potassium content in grain also influenced by KSB isolates. Isolates KSB 107 was recorded for maximum $\mathrm{K}$ content in grain $(0.51 \%)$ followed by KSB 28 and KSB 36. 
Out of $15 \mathrm{KSB}$ isolates, 7 isolates showed significant superiority in $\mathrm{N} \%$ of plant over the control. Nitrogen per cent was more in grain than straw. Highest $\mathrm{N} \%$ in grain was recorded with KSB 107 (1.99\%). Maximum $\mathrm{N}$ content in straw was recorded equally in KSB 107 and KSB $111(0.44 \%)$ which is increased by 29 per cent compare to control showed in table 4.

Maximum phosphorus content was observed with KSB 37 (0.145\%). Phosphorus content in grain and straw was significantly influenced by various KSB isolates. KSB 107 caused maximum $\mathrm{P}$ content in straw which was insignificantly greater than KSB 36 and KSB 48. Isolate KSB 48 gave maximum $\mathrm{P}$ content in grain which was insignificantly higher than KSB 107 and KSB 28. Out of 15 $\mathrm{KSB}$ isolates, $12 \mathrm{KSB}$ isolates were significantly superior to control. KSB 107 gave $54.5 \%$ more phosphorus in grain than control.

KSB 107 appeared to be the effective isolates is causing greater $\mathrm{N}$ uptake in grain and straw than other treatments. Maximum $\mathrm{N}$ uptake by straw was recorded with KSB 107 (40 mg pot $^{1}$ ) which was at par with $3 \mathrm{KSB}$ isolates. All the KSB isolates were significantly superior to control except isolate KSB 9. Out of $15 \mathrm{KSB}$ isolates, $13 \mathrm{KSB}$ isolates showed significant superiority of $\mathrm{N}$ uptake in grain over control. KSB 9 and KSB 15 were caused non-significantly more $\mathrm{N}$ uptake than control showed in table 5. Phosphorus up take by straw and grain was significantly influenced by various KSB isolates. KSB 48 gave highest $\left(6.2 \mathrm{mg} \mathrm{pot}^{-1}\right)$ and significantly more $P$ uptake by straw than control and insignificantly greater than KSB 107 (5.4 mg $\left.\operatorname{pot}^{-1}\right)$. Thirteen KSB isolates were significantly superior to control. KSB 48 gave highest (30 mg pot ${ }^{-1}$ ) $\mathrm{P}$ uptake by grain which was at par with KSB 37 and KSB 107. Twelve KSB isolates showed their significant superiority over control. Potassium uptake in straw and grain was significantly influenced by various KSB isolates. Isolate KSB 107 caused maximum (155 $\left.\mathrm{g} \mathrm{pot}^{-1}\right)$ and significant $\mathrm{K}$ uptake by straw than the all isolates. Out of $15 \mathrm{KSB}$ isolates, $14 \mathrm{KSB}$ isolates were significantly superior in $\mathrm{K}$ uptake to control. KSB 9 gave insignificantly lower $\mathrm{K}$ uptake in straw than control. KSB 107 showed maximum and significantly greater $\mathrm{K}$ uptake value grain in-comparison to other $\mathrm{KSB}$ isolates. All the KSB isolates caused control

In conclusion application of KSB on soilplant system can be a valuable tool for increased crop productivity. Therefore it has been examined the potentiality of KSBs on yield, growth and nutrient uptake attributes. Maximum straw yields and total biomass were recorded with isolates KSB 107 and also plant height significantly higher $(64.39 \mathrm{~cm})$ as well as maximum $\mathrm{K}$ content in grain $(0.51 \%)$ by KSB107. Finally it can be concluded that seed inoculation of KSB influenced growth and yields of wheat crop. Increase in $\mathrm{K}$ content in wheat plant and increase nutrient uptake at harvest in crop showed significance of K-solubilizers in supply of potassium to crop and enrichment of soil with potassium.

\section{Acknowledgement}

The senior author would like to thank Department of soil science and agricultural chemistry, IAS, BHU, Varanasi and also like to thank ICAR for Junior Research Fellowship for Master Degree

\section{References}

Aleksandrov, V.G., Blagodyr, R.N. and Iiiev, I.P. 1967. Liberation of phosphoric acid from apatite by silicate bacteria. Mikrobiyol Zh. (Kiev). 29: 111-114.

Archana, D.S., Nandish, M.S., Savalagi, V.P. and Alagawadi, A.R. 2013. 
Characterization of potassium solubilizing bacteria (KSB) from rhizosphere soil.Bioinfolet. 10: 248257.

Archana, D.S.; Savalgi, V.P. and Alagawadi, A.R. 2008. Effect of potassium solubilizing bacteria on growth and yield of maize. Soil Biol. Ecol. 28(12): 9-18.

Bagyalakshmi B, Nithya B, Ponmurugan P. 2009. Studies on potassium solubilizing bacteria from Southern Indian tea soils, in: P.Ponmurugan, B.Nithya (Eds.), Guidelines for Entrepreneurship development programme to biotechnology graduates, Excel India Publishers, New Delhi, pp. 71-76.

Barker, W.W., Welch, S.A., Chu, S. and Banfield, F. 1998. Experimental observations of the effects of bacteria on aluminosilicates weathering. Amer. Mineral. 83: 1551 - 1563.

Deng, S.B., Bai, R.B., Hu X.M., and Luo Q. 2003. Characteristics of a bioflocculant produced by Bacillus mucilaginosus and its use in starch wastewater treatment. Applied Microbiology and Biotechnology. 60: 588-593

Goldstein, A.H. 1994.. Involvement of the quino protein glucose dehydrogenase in the solubilization of exogeneous mineral phosphates by gram negative bacteria. In phosphate in microorganisms: cellular and molecular biology. Cell. Mol. Biol., Eds. 197-203

Hu, X.F., Chen, J. and Guo, J.F. 2006. Two phosphate and potassium soluilizing bacteria isolated from Tiannu mountain, Zhejiang, China. World J. Miccro. Biotech. 22: 983 - 990. Muentz, A. 1890 Surla decomposition desroches etla formation de la terre arable. C. R. Acad Sci. 110:13701372.

Xie, J.C. 1998. Present situation and prospects for the world's fertilizer use. Plant Nutrition and Fertility Science 4: 321-330.

\section{How to cite this article:}

Gajendra Meena and Bihari Ram Maurya. 2017. Potentiality of Potassium Solubilizing Bacteria on Enhancing the Growth, Yield and Nutrient Acquisition on Wheat (Triticum aestivum L.). Int.J.Curr.Microbiol.App.Sci. 6(4): 2443-2450. doi: https://doi.org/10.20546/ijcmas.2017.604.285 